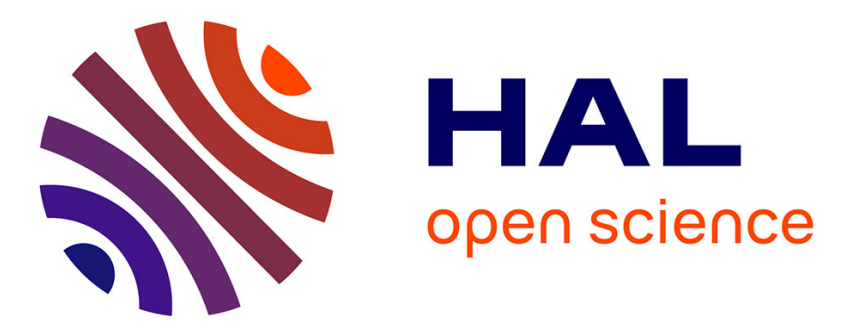

\title{
Preliminary investigation on the presence of peptides inhibiting the growth of Listeria innocua and Listeria monocytogenes in Asiago d'Allevo cheese
}

Lignitto, Segato, Balzan, Cavatorta, Oulahal, Sforza, Degraeve, Galaverna, Novelli

\section{To cite this version:}

Lignitto, Segato, Balzan, Cavatorta, Oulahal, et al.. Preliminary investigation on the presence of peptides inhibiting the growth of Listeria innocua and Listeria monocytogenes in Asiago d'Allevo cheese. Dairy Science \& Technology, 2012, 92 (3), pp.297-308. 10.1007/s13594-012-0057-6 . hal00930620

\section{HAL Id: hal-00930620 \\ https://hal.science/hal-00930620}

Submitted on 1 Jan 2012

HAL is a multi-disciplinary open access archive for the deposit and dissemination of scientific research documents, whether they are published or not. The documents may come from teaching and research institutions in France or abroad, or from public or private research centers.
L'archive ouverte pluridisciplinaire HAL, est destinée au dépôt et à la diffusion de documents scientifiques de niveau recherche, publiés ou non, émanant des établissements d'enseignement et de recherche français ou étrangers, des laboratoires publics ou privés. 


\title{
Preliminary investigation on the presence of peptides inhibiting the growth of Listeria innocua and Listeria monocytogenes in Asiago d'Allevo cheese
}

\author{
Laura Lignitto • Severino Segato • Stefania Balzan • \\ Valeria Cavatorta • Nadia Oulahal • Stefano Sforza • \\ Pascal Degraeve • Gianni Galaverna • Enrico Novelli
}

Received: 19 July 2011 / Revised: 9 December 2011 / Accepted: 16 January 2012 / Published online: 22 February 2012

(C) INRA and Springer-Verlag, France 2012

\begin{abstract}
Bacteriocins produced by some strains of lactic acid bacteria or antimicrobial casein fragments can be released into the water-soluble fraction of cheeses during ripening. However, there is a lack of experimental evidence which supports the theory that these peptides can exert an effective antimicrobial effect. The aim of this study was to investigate the anti-listerial activity of such peptides in Asiago d'Allevo cheese. The water-soluble fraction of Asiago was ultrafiltrated through $10 \mathrm{kDa}$ cutoff membranes before being dialyzed (100-500 Da cut-off) to remove proteins, salts, and organic acids, prior to freeze-drying. The growth of Listeria innocua LRGIA 01 and of Listeria monocytogenes strain 162 in Brain Heart Infusion (BHI) at $30{ }^{\circ} \mathrm{C}$ in the presence or absence of 5 to $40 \mathrm{mg} \cdot \mathrm{mL}^{-1}$ of cheese water-soluble extracts (WSEs) lyophilisate was monitored spectrophotometrically. WSEs lyophilisates from cheeses of different production systems (total mixed-ration-fed cows and cheese-making in a dairy plant in May; alpine-grazing cows and cheese-making in situ in July and
\end{abstract}

L. Lignitto $\cdot$ S. Segato $(\square)$

Department of Animal Science, University of Padova, 35020 Legnaro, PD, Italy

e-mail: severino.segato@unipd.it

S. Balzan • E. Novelli

Department of Public Health, Comparative Pathology and Veterinary Hygiene, University of Padova, 35020 Legnaro, PD, Italy

V. Cavatorta $\cdot$ S. Sforza $\cdot$ G. Galaverna

Department of Organic and Industrial Chemistry, University of Parma, 43124 Parma, Italy

N. Oulahal · P. Degraeve

Université Lyon 1-ISARA Lyon, Bioingénierie et Dynamique Microbienne aux Interfaces Alimentaires (EA n³733), IUT Lyon 1 site de Bourg en Bresse, Technopole Alimentec, Université de Lyon, rue Henri de Boissieu, 01000 Bourg en Bresse, France 
September) and ripened for 6, 12, and 18 months were tested. A limited dosedependent inhibition of growth was observed at all the assayed concentrations. The addition of cheese WSEs lyophilisates to BHI broth inhibited the growth of $<50 \%$ of L. innocua LRGIA 01 and $<10 \%$ of L. monocytogenes strain 162 . Antilisterial activity was only significantly affected by ripening time (it was maximal at 6 months). Quantification of peptides with a sequence similar to the antimicrobial casein fragments $\alpha_{\mathrm{S} 1}-\mathrm{CN} f(1-23)$ (isracidin) and $\alpha_{\mathrm{S} 2}-\mathrm{CN} \mathrm{f}(183-207)$ in cheese WSEs suggests that their anti-listerial activity is likely also to be due to other peptides.

\section{肽对 Asiago d'Allevo 干酪中李斯特英诺克菌和李斯特单胞菌的抑制作用}

摘要 某些乳酸菌能产生抗菌素, 此外, 在干酪成熟过程中会产生一些水溶性的、具有抗菌性 能的酪蛋白片段。尽管理论上认为这些肽具有杀菌的作用, 但还是缺少实验数据证明这种可 能性。本文研究了肽对 Asiago d'Allevo 干酪中李斯特菌的抑制作用。Asiago d'Allevo 干酪 的水溶性部分经过 $10 \mathrm{kDa}$ 的膜超滤, 超滤液又经过 100-500 Da 的渗透膜渗析后除去蛋白、 盐和有机酸, 超滤液冻干。将李斯特英诺克 LRGIA 01 和李斯特单胞菌 162 分别接种于含有 $5-40 \mathrm{mg} \cdot \mathrm{mL}^{-1}$ 冻干的干酪水溶性提取物 (WSEs) 的BHI培养基中, 在 $30{ }^{\circ} \mathrm{C}$ 下培养, 并检测李 斯特菌的生长情况。WSEs 冻干物分别来源于不同的原料和成熟期的 Asiago d'Allevo 干 酪, 原料奶的来源分别为 5月 (种植牧草)、7月和9月 (高山自然放牧), 成熟期为 $6 、 12 、 18$ 个月。在所有的浓度范围内, 部分数据显示出剂量与抑制作用的关系。WSEs冻干物对李斯 特英诺克 LRGIA 01 生长的抑制率 $<50 \%$, 对李斯特单胞菌 162 的抑制率 $<10 \%$ 。干酪的成 熟时间 (至少 6 个月) 显著地影响 WSEs 冻干物对李斯特菌的抑制作用。采用与 WSEs 序列 类似的并具有抗菌作用的酪蛋白片段 $\alpha_{\mathrm{S}_{1}-} \mathrm{CN} f(1-23)$ (isracidin) 和 $\alpha_{\mathrm{S} 2}-\mathrm{CN}$ f(183-207) 进行 定量试验, 结果证明了, WSEs 冻干物具有抑制李斯特菌的特性可能是来源于其他的肽。

Keywords Antibacterial peptides - Listeria . Cheese production system - Cheese ripening

关键词 抗菌肽·李斯特菌·干酪生产·干酪成熟

\section{Introduction}

Milk is an optimal source of nutrients and contains substances that are effective against infections (McCann et al. 2005). The antibacterial activity of milk is attributed both to immunoglobulins and to non-immune proteins such as lactoferrin, lactoperoxidase and lysozyme (Floris et al. 2003). Furthermore, several antimicrobial peptides (AMPs) derived from milk proteins have been characterized in dairy products such as fermented milk and various cheeses (Lahov and Regelson 1996; Rizzello et al. 2005; Zucht et al. 1995). AMPs can be released from lactoferrin, $\alpha_{\mathrm{s} 1}$-casein (CN), $\alpha_{\mathrm{s} 2}-\mathrm{CN}, \kappa-\mathrm{CN}, \alpha$-lactalbumin, and $\beta$-lactoglobulin (López Expósito and Recio 2006) by enzymatic proteolysis especially during milk processing or cheese ripening (Gobbetti et al. 2004).

AMPs derived from caseins are able to kill target cells rapidly, while having a broad spectrum of activity, which allows them to overcome the antibiotic-resistant pathogens (McCann et al. 2006; Zucht et al. 1995). They might be useful in food industry to limit the growth of Listeria monocytogenes and other pathogens 
commonly introduced into dairies and other food-processing plants through the raw materials, including milk (Adrião et al. 2008). Few reports have considered cheeses as a potential source of AMPs. Pritchard et al. (2010) have shown that three peptides present in commercial Australian Cheddar cheese exhibited antimicrobial activities against Escherichia coli ATCC 8739, Staphylococcus aureus ATCC 6538, and Bacillus cereus ATCC 11778. Rizzello et al. (2005) reported that Pecorino Romano, Canestrato Pugliese, Crescenza, and Caprino del Piemonte, which are characterized by short or medium ripening periods, contained several AMPs that were able to inhibit the growth of Listeria innocua DSM 20649. On the contrary, these authors also observed that Parmigiano-Reggiano, Fossa, and Gorgonzola water-soluble extracts (WSE) did not contain any AMPs, suggesting that the prolonged ripening time and the high level of proteolysis led to a subsequent degradation of antimicrobial peptides into inactive fragments.

The objective of this study was to assess the antimicrobial activity against Listeria spp. of WSEs of Asiago d'Allevo cheese, a PDO semi-hard cheese made with raw bovine milk produced in the region of Veneto, Italy. For this purpose, cheeses produced in different production systems in May, July, and September and ripened for 6,12 , or 18 months were sampled. The main oligopeptides present in Asiago cheese WSEs were identified by reversed-phase high-performance liquid chromatography/electrospray ionization-mass spectrometry (RP-HPLC/ESI-MS). The sequences of these oligopeptides were compared with known sequences of antimicrobial fragments of caseins. The concentrations of the peptides known to exert an antimicrobial activity and of the closely related peptides in the different cheese samples were then determined in order to check whether their concentrations were correlated with their anti-listerial activity.

\section{Materials and methods}

\subsection{Cheese sampling and cheese-making procedures}

The trial was carried out in an alpine dairy farm (Veneto region, Italy) that reared around 50 lactating Holstein-Friesian cows. The cheeses sampled out were produced with milk obtained under three different management and feeding conditions: A, at the end of spring, when cows were stall-housed in a barn and fed a total mixed ration; $\mathrm{B}$, in the middle of summer, when cows were fed with alpine pasture plus a concentrate supplement; $\mathrm{C}$, at the end of summer, when cows were kept under similar conditions to the latter. The Asiago d'Allevo samples were manufactured with raw, partially skimmed milk in a commercial dairy plant in the case A and in an artisanal dairy plant belonging to the farm (in situ) in the cases B and C. Cheese-making procedure following the Italian official protocol included the use of starter culture (a mixture of Streptococcus thermophilus and Lactobacillus delbrueckii subsp. bulgaricus) and rennet (see Segato et al. 2007 and Lignitto et al. 2010 for more details). According to a $3 \times 3$ experimental design, the sampling scheme adopted considered three cheese production systems (A, B, and C) and three lengths of ripening time: 6 , 12 , or 18 months. 
WSEs were obtained according to the procedure described in Lignitto et al. (2010). The only modification consisted in adding - after the ultrafiltration through polyethersulfone membranes (10 kDa cut-off, Millipore, St Quentin en Yvelines, France) step to remove high-molecular-mass molecules - a WSE dialysis against Milli-Q water for $48 \mathrm{~h}$ at $4{ }^{\circ} \mathrm{C}$ step in order to remove the salts. Cellulose ester dialysis membranes of 100-500 Da cut-off (Spectra/Por ${ }^{\circledR}$ Float-A-Lyzer ${ }^{\circledR}$, Breda, NL) were used. The $\mathrm{pH}$ of the recovered solution was adjusted to $7.5 \mathrm{using} 10 \mathrm{~mol} \cdot \mathrm{L}^{-1} \mathrm{NaOH}$. Finally, the WSEs were freeze-dried and kept at $-20{ }^{\circ} \mathrm{C}$ until use. Before the antimicrobial assay, the WSEs were re-hydrated in BHI broth (Biolife, Milano, Italy) at final concentrations of $5,15,30$, or $40 \mathrm{mg} \cdot \mathrm{mL}^{-1}$ and then filtered through a $0.2 \mu \mathrm{m}$ surfactant-free cellulose acetate membrane (Sartorius Biotech $\mathrm{GmbH}$, Goettingen, Germany) to obtain a sterile solution. The salt concentration of re-hydrated WSE was measured using a chloride analyzer (Sherwood 926, Goldaming, UK) in order to verify that salt (sodium chloride) was removed during the dialysis step.

\subsection{Anti-listerial activity assays of Asiago cheese WSEs}

L. innocua LRGIA 01 (Chadeau et al. 2010) and L. monocytogenes strain 162 (Aerial collection, Illkirch, France; Mariani et al. 2011) were isolated from an industrial plant and from brine solution used for salting of cheese, respectively. One milliliter of each stock culture of bacteria (stored at $-80^{\circ} \mathrm{C}$ in BHI broth (Biolife) supplemented with $20 \%(v / v)$ glycerol) was thawed in $9 \mathrm{~mL}$ of BHI broth and incubated at $30{ }^{\circ} \mathrm{C}$ for $8 \mathrm{~h}$. A second subculture was then performed under the same conditions. Lag-phase cells thus obtained were then diluted 1:20 to obtain a final suspension that contained approximately $10^{8}$ colony-forming units (cfu) per milliliter and that was employed to inoculate sterile 96-well microtiter plates. The cheese WSEs lyophilisates were resuspended in BHI broth at four concentrations $\left(5,15,30\right.$, and $\left.40 \mathrm{mg} \cdot \mathrm{mL}^{-1}\right)$. In each well, $270 \mu \mathrm{L}$ of the BHI broth with or without (positive control) WSE lyophilisate were mixed with $30 \mu \mathrm{L}$ of bacterial inoculum. The negative control wells contained $30 \mu \mathrm{L}$ of bacterial inoculum and $270 \mu \mathrm{L}$ of the well-known bacteriocin nisin (at a final concentration of $2,400 \mathrm{IU} \cdot \mathrm{mL}^{-1}$ ) resuspended in BHI broth to inhibit Listeria spp. growth. A $10,000 \mathrm{IU} \cdot \mathrm{mL}^{-1}$ nisin stock solution was prepared by dissolving Nisaplin ${ }^{\circledR}$ powder (commercial preparation, $2.5 \%(w / w)$ of purity, SigmaAldrich) in $0.02 \mathrm{~mol} \cdot \mathrm{L}^{-1} \mathrm{HCl}$. The $\mathrm{pH}$ of BHI broth after nisin stock solution addition to concentrated BHI broth was adjusted to 7.5 using $10 \mathrm{~mol} \cdot \mathrm{L}^{-1} \mathrm{NaOH}$. Bacterial cultures growth at $30{ }^{\circ} \mathrm{C}$ was monitored hourly over a 10 -h period with a final measurement after $24 \mathrm{~h}$ by measuring the optical density at $620 \mathrm{~nm}\left(\mathrm{OD}_{620 \mathrm{~nm}}\right)$ using a microplate reader (DTX800, Beckman Coulter, Orange County, CA, USA). When bacterial growth was inhibited by the cheese WSEs lyophilisates, bacterial cells were recovered from microplates and inoculated in fresh BHI broth for $24 \mathrm{~h}$ at $30{ }^{\circ} \mathrm{C}$. This allowed checking whether cheese WSEs lyophilisates had bacteriostatic or bactericidal action. All the experiments were performed in triplicate; the mean $\mathrm{OD}_{620 \mathrm{~nm}}$ and the corresponding standard deviations were then calculated for each condition. The percent inhibition of bacterial growth was determined by subtracting the $\mathrm{OD}_{620 \mathrm{~nm}}$ in wells containing WSE lyophilisate from the $\mathrm{OD}_{620 \mathrm{~nm}}$ in positive control wells, 
dividing this difference by the $\mathrm{OD}_{620 \mathrm{~nm}}$ in positive control wells, and multiplying by 100. Moreover, it was verified that a total $(100 \%)$ inhibition of bacterial growth was observed in negative control wells.

\subsection{LC/ESI-MS analysis}

The cheese WSEs (ultrafiltrated onto $10 \mathrm{kDa}$ cut-off membranes to remove molecules with molecular masses above $10 \mathrm{kDa}$ ) were analyzed by RP-HPLC/ESI-MS. The conditions are described in Lignitto et al. (2010), with slight modifications. Briefly, the HPLC equipment consisted of a Waters Alliance 2695 (Waters, Milford, MA, USA) separation module equipped with a Gemini (Phenomenex, Torrance, CA, USA) $\mathrm{C}_{18}$ column $(5 \mu \mathrm{m}, 300 \AA, 250 \times 4.6 \mathrm{~mm})$ connected to a Micromass ZMD mass spectrometer (Micromass, Manchester, UK). Gradient elution was performed with eluent $\mathrm{A}, \mathrm{H}_{2} \mathrm{O}$ containing $0.2 \% \mathrm{CH}_{3} \mathrm{CN}$ and $0.1 \% \mathrm{HCOOH}$ and eluent $\mathrm{B}, \mathrm{CH}_{3} \mathrm{CN}$ containing $0.2 \% \mathrm{H}_{2} \mathrm{O}$ and $0.1 \% \mathrm{HCOOH}$. The following gradient was applied: 0 $15 \mathrm{~min}$ isocratic $100 \% \mathrm{~A}, 15-60$ min linear gradient from $100 \%$ A to $67 \% \mathrm{~A}, 60$ $69 \mathrm{~min}$ isocratic $67 \% \mathrm{~A}, 69-70 \mathrm{~min}$ from $67 \%$ to $60 \% \mathrm{~A}, 70-80 \mathrm{~min}$ from $60 \%$ A to $0 \% \mathrm{~A}, 80-85 \mathrm{~min}$ isocratic $0 \% \mathrm{~A}$, plus reconditioning (85-90 min to $100 \% \mathrm{~A}$ ); flow rate, $1 \mathrm{~mL} \cdot \mathrm{min}^{-1}$; MS conditions: ESI interface with $90 \%$ splitting of the column flow; positive ions; single quadrupole analyzer; capillary voltage, $3.2 \mathrm{kV}$; cone voltage, $30 \mathrm{~V}$; source temperature, $100{ }^{\circ} \mathrm{C}$; desolvation temperature, $150{ }^{\circ} \mathrm{C}$; cone gas $\left(\mathrm{N}_{2}\right), 100 \mathrm{~L} \cdot \mathrm{h}^{-1}$; desolvation gas $\left(\mathrm{N}_{2}\right), 450 \mathrm{~L} \cdot \mathrm{h}^{-1}$; acquisition of total ion chromatograms (TIC, 100-1,900 m/z): scan time, $3 \mathrm{~s}$; inter-scan delay, $0.1 \mathrm{~s}$. HPLCMS chromatograms were elaborated in order to identify characteristic ions, molecular weights (MWs), retention times and in source CID fragments (if present) of the main peaks. MW determination was confirmed by MaxEnt application of Mass Lynx Software in the case of MWs >1,000 Da. Peptide identification was performed by applying an original procedure previously developed (Sforza et al. 2003). Peak area integration for each peptide was performed automatically by QuanLynx Software, after obtaining the corresponding extract ion chromatogram (XIC technique). Integration parameters include automatic ApexTrack Peak Integration and Noise measurement; smooth parameters, \pm 1 scans and 1 smooth by "mean" method. After a correction for moisture content, each peptide was semi-quantified by the ratio obtained dividing its peak area by the area of the internal standard (Phe-Phe) in the same sample.

\subsection{Statistical analysis}

The assumption of normality of the residual plot was checked using the ShapiroWilks test (PROC Univariate). Bacterial growth inhibition data were analyzed as repeated measures using a mixed procedure with a CS (compound symmetry) structure. The linear model for both bacterial strains was:

$$
Y_{\mathrm{ijklm}}=\mu+R_{\mathrm{i}}+M_{\mathrm{j}}+c_{\mathrm{ij}}+P_{\mathrm{k}}+T_{1}+\beta B_{\mathrm{ijk}}+\beta A_{\mathrm{ijk}}+\varepsilon_{\mathrm{ijklm}}
$$

where $Y$ is the response for growth inhibition, $\mu$ is the overall mean, $R_{\mathrm{i}}$ is the length of ripening time effect (three levels: 6,12 , and 18 months), $M_{\mathrm{j}}$ is the cheese production 
system effect (three levels: end of spring/barn/commercial dairy plant, A; middle of summer/alpine-grazing/artisanal dairy plant, B; end of summer/alpine-grazing/artisanal dairy plant, C), $c_{\mathrm{ij}}$ is the random effect of each cheese form nested within $R$ and $M, P_{\mathrm{k}}$ is the Asiago cheese WSE lyophilisate concentration effect (four levels: 5, 15, 30, and $40 \mathrm{mg} \cdot \mathrm{mL}^{-1}$ ), $T_{1}$ is the time of incubation as repeated effect (four levels: 7, 8, 9, and $10 \mathrm{~h}), \beta$ is the regression coefficient, $B_{\mathrm{ijk}}$ is the $\log _{10} \mathrm{cfu} \cdot \mathrm{mL}^{-1}$ of bacterial concentration covariate, $A_{\mathrm{ijk}}$ is the residual salt concentration in Asiago cheese WSE lyophilisates covariate, and $\varepsilon_{\mathrm{ijklm}}$ is the random residual. No interactions among fixed effects resulted statistically significant, thus they were not introduced in the model. The degrees of freedom of $R$ effect were used in two orthogonal contrasts: 6 versus $(12+18) / 2$ months; 12 versus 18 months. When an effect was significant $(P<0.05)$, differences among levels of treatment means were determined using the PDIFF option along with Bonferroni adjust. All statistical analyses were carried out by using the SAS ${ }^{\circledR}$ software (SAS Institute, Cary, NC, USA).

\section{Results and discussion}

\subsection{Anti-listerial activity of Asiago cheese water-soluble extracts}

It was first verified that the residual sodium chloride quantity present in lyophilisates of dialyzed and ultrafiltrated WSEs of Asiago cheese added to BHI broth did not significantly affect either L. innocua LRGIA 01 or L. monocytogenes strain 162 growth $\left(P>0.10\right.$ for both strains). This is consistent with the less than $10 \mathrm{mg} \cdot \mathrm{mL}^{-1}$ sodium chloride concentration added in BHI broth resulting from Asiago d'Allevo cheese WSEs lyophilisates addition.

The effect of the cheese production system was not significant $(P=0.51)$ on $L$. innocua LRGIA 01 growth inhibition as well as the length of ripening time of Asiago cheese $(P=0.11)$. However, according to the orthogonal contrasts [cheeses ripened for 6 months versus (cheeses ripened for 12 or 18 months/2); $P<0.05$ ], the percentages of inhibition of L. innocua LRGIA 01 growth induced by the addition to BHI broth of lyophilisates of Asiago cheese WSEs ripened for 6 months (26.4\% on average) were higher than after addition of lyophilisates of Asiago cheese WSEs ripened for 12 (20.1\% on average) or 18 months ( $18.1 \%$ on average). Since inhibition of L. monocytogenes strain 162 growth by WSEs lyophilisates was limited (always less than $12 \%)$, both the effects of the cheese production period $(P=0.23)$ and of the length of ripening time $(P=0.43)$ were not significant $(P>0.10)$. Taken together, these observations on the effect of the length of cheese ripening time on the inhibition of the two Listeria strains considered are consistent with those of Rizzello et al. (2005). These authors reported that Pecorino Romano, Canestrato Pugliese, Crescenza, and Caprino del Piemonte, which are characterized by short or medium ripening periods, contained several AMPs that were able to inhibit the growth of L. innocua DSM 20649. On the contrary, WSE from hard cheeses (Parmigiano-Reggiano, Fossa, and Gorgonzola) did not contain any AMPs. Therefore, they suggested that the high level of proteolysis resulting from a prolonged ripening led to a subsequent degradation of AMPs into inactive fragments. Rizzello et al. (2005) also noticed that cheeses characterized by a $\mathrm{SN}$ (soluble nitrogen)/TN (total nitrogen) ratio that ranged from 
$12 \%$ to $24 \%$ generally contained higher amounts of bioactive peptides. The Asiago cheese samples ripened for 6 months were characterized by a significantly $(P<0.05)$ lower SN/TN ratio $(21.4 \%)$ when compared with the samples matured for $12(26.1 \%)$ and 18 months (27.6\%) (unpublished data). This could explain why WSEs of Asiago cheeses ripened for 18 and to a lesser extent 12 months had a lower anti-listerial activity than those of cheeses ripened for 6 months. With specific regard for the experimental conditions tested in the present investigation, it is quite interesting to observe the absence of differences among Asiago cheeses produced in the commercial dairy plant and those manufactured in the artisanal dairy plant (in situ). As already noted for the ACE inhibitory peptides in Asiago d'Allevo cheese (Lignitto et al. 2010), the combined effect of the proteases of lactic acid bacteria and the action of chymosin with the mild heating $\left(45^{\circ} \mathrm{C}\right)$ treatment of inducing a plasmin activation are most likely responsible for the AMPs generation in Asiago d'Allevo cheese. Antilisterial activity, in the light of our results, did not depend on the cheese production system, suggesting that the origin of AMPs is not influenced neither by the milk productive method (farm vs. alpine grazing), nor by cheese-making conditions (commercial dairy plant vs. farmhouse). Taking into account the absence of significant difference between dairy plant and farmhouse cheese-making, the contribution of autochthonous bacteria was likely negligible, and/or their effect was covered by that of starter LAB.

The only fixed effect that appeared significant $(P=0.03)$ for L. monocytogenes strain 162, although to a lesser extent than for L. innocua LRGIA $01(P<0.001)$, was the effect of Asiago d'Allevo cheese WSE lyophilisate concentration in BHI broth. Therefore, the percents of growth inhibition after $10 \mathrm{~h}$ incubation in BHI broth supplemented with 5 to $40 \mathrm{mg}$ of WSEs lyophilisates per milliliter are presented in Fig. 1 for the two strains. The percentage of inhibition of L. innocua LRGIA 01 increased quite linearly with WSE concentration in BHI broth (Fig. 1a). Unlike for $L$. innocua LRGIA 01, it appeared that the concentrations of cheese WSE lyophilisates in BHI broth above $15 \mathrm{mg} \cdot \mathrm{mL}^{-1}$ did not cause any further significant improvement in the inhibition of L. monocytogenes strain 102 (Fig. 1b). Once L. innocua LRGIA 01 cells recovered from BHI broth containing up to $40 \mathrm{mg} \cdot \mathrm{mL}^{-1}$ cheese, WSE lyophilisates were inoculated in fresh BHI broth without cheese WSE lyophilisate; no more inhibition of their growth was observed (data not shown). This suggests that the molecules present in the WSE lyophilisates displayed a bacteriostatic rather than a bactericidal mode of action when less than $40 \mathrm{mg}$ of WSE lyophilisate per milliliter was added to BHI broth.

The anti- $L$. innocua LRGIA 01 activity of Asiago cheese WSEs was always significantly higher than their anti-L. monocytogenes strain 162 activity. This is in accordance with the observation that the sensitivity of Listeria to AMPs depends on the species considered. However, since it also depends on the strain for each species (Alvarez-Cisneros et al. 2010), and namely on its serotype for L. monocytogenes strains (Mukherjee et al. 2011), the anti-listerial activity of Asiago cheese WSEs should be assayed with a larger panel of L. innocua and L. monocytogenes strains including other serotypes than the serotype of $L$. monocytogenes strain 162 (serotype $1 / 2$ a), before it could be proposed that L. innocua is more sensitive to Asiago cheese WSEs than L. monocytogenes.

The lyophilisates added to BHI broth were prepared from WSEs of Asiago cheese prepared by mixing one weight of grated cheese with twice its weight of water. They 
Fig. 1 Relationship between cheese WSE lyophilisate concentration (milligrams per milliliter) and percentage of growth inhibition (percent) of L. innocua LRGIA 01 (a) or L. monocytogenes strain 162 (serotype 1/2a) (b). Data with a different letter differ at $P<0.01$ (L. innocua) or $P<0.05$ (L. monocytogenes)
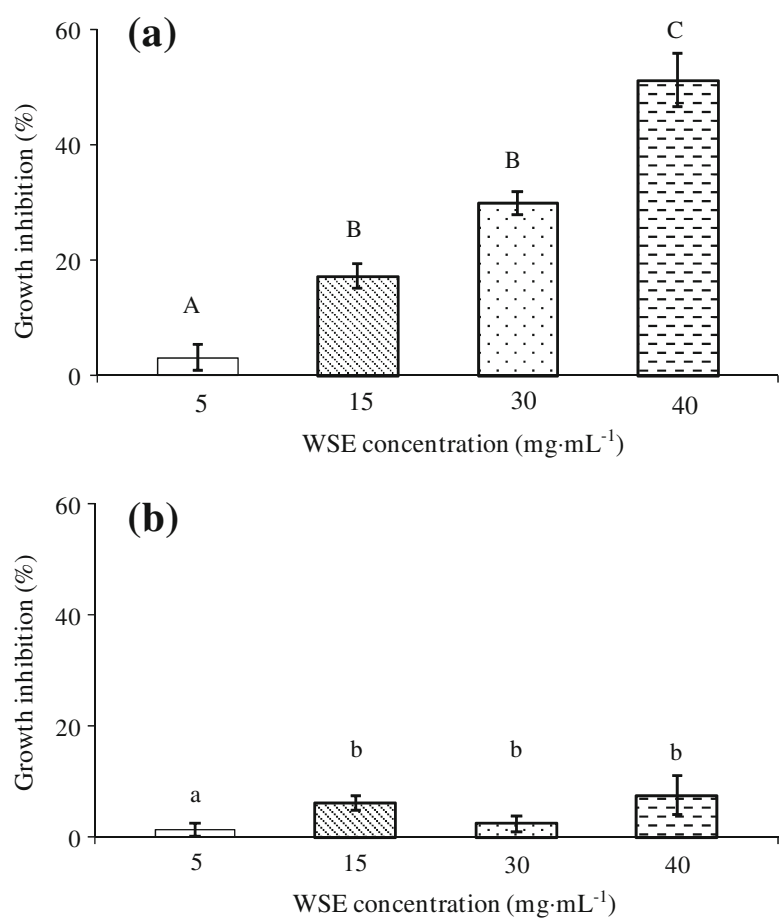

were subsequently ultrafiltrated onto $10 \mathrm{kDa}$ cut-off membranes and dialyzed to remove proteins and salt, respectively. These extracts contained around $20 \mathrm{~g} \cdot \mathrm{L}^{-1}$ of nitrogenous compounds with a molecular weight lower than $10 \mathrm{kDa}$ : their concentration in cheese exceeded thus $6 \%(w / w)$. Since Asiago cheese contains less than $40 \%(w / w)$ water, the concentration of NPN compounds in the aqueous phase of Asiago cheese exceeds $15 \%(w / w)$ (i.e., $\left.\sim 150 \mathrm{~g} \cdot \mathrm{L}^{-1}\right)$. The highest cheese WSE lyophilisate concentration added in BHI broth (i.e., $40 \mathrm{mg} \cdot \mathrm{mL}^{-1}$ ) was thus far lower than the theoretical peptide concentration in Asiago d'Allevo cheese. Although the aqueous phase of cheese also contains organic acids, such as lactic acid and sodium chloride that could contribute to the inhibition of the growth of bacteria such as $L$. monocytogenes, a contribution of the AMPs present in Asiago d'Allevo cheese can thus not be excluded and deserves further study, even if in this study it seems of minor practical importance.

\subsection{Identification of peptides present in Asiago cheese WSEs lyophilisates}

The identification of the peptides was performed according to a well-defined mass spectrometry procedure, already used to identify proteolytic peptides in cheese (Sforza et al. 2003). For every peak (peptide) of the chromatogram, the corresponding characteristic $\mathrm{m} / \mathrm{z}$ values of higher intensity were obtained. On the basis of the MS spectrum, the molecular weight of the peptide was obtained and directly matched with the possible compatible casein sequences. Moreover, the theoretical fragments generated after the loss of the first $\mathrm{N}$ - or C-terminal amino acids by all the compatible 
peptides can be calculated, and by comparing the theoretical fragments with the real ones present in the spectrum, generated by the in-source fragmentation, the identification of peptides can be achieved in most cases. By this approach, 49 proteolytic casein-derived peptides found in the sample extracts were identified and reported in Table 1 (peptides coming from $\alpha_{\mathrm{s} 1^{-}}$and $\alpha_{\mathrm{s} 2}$-casein) and Table 2 (peptides coming from $\beta$-casein). Among the 49 identified peptides, two were antimicrobial fragments of caseins previously identified in the literature: $\alpha_{\mathrm{s} 1}-\mathrm{CN} f(1-23)$ called isracidin and $\alpha_{\mathrm{s} 2}$-CN $f(183-207)$. Isracidin has demonstrated antibiotic-type activity in vivo against $S$. aureus and Candida albicans (Lahov and Regelson 1996). In vitro growth inhibition of lactobacilli and other Gram-positive bacteria by isracidin was also

Table 1 Identified peptides originated from $\alpha_{\mathrm{S} 1}$-casein and $\alpha_{\mathrm{s} 2}$-casein found in Asiago d'Allevo cheese

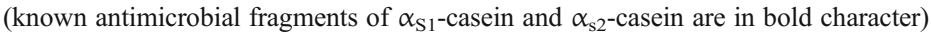

\begin{tabular}{|c|c|c|}
\hline Identification & MW & Characteristic ions $(\mathrm{m} / \mathrm{z})$ \\
\hline$\alpha_{\mathrm{S} 1} \mathrm{CNf}(18-21)$ & 487 & $488.4\left(\mathrm{MH}^{+}\right)+357.4(\mathrm{~b} 3)$ \\
\hline$\alpha_{\mathrm{S} 1} \mathrm{CNf}(27-30)$ & 489 & $489.3\left(\mathrm{MH}^{+}\right)+342.3(\mathrm{y} 3)$ \\
\hline$\alpha_{\mathrm{S} 1} \mathrm{CNf}(17-21)$ & 601 & $602.4\left(\mathrm{MH}^{+}\right)$ \\
\hline$\alpha_{\mathrm{S} 1} \mathrm{CNf}(24-30)$ & 805 & $806.4\left(\mathrm{MH}^{+}\right)+403.7\left(\mathrm{MH}_{2}{ }^{2+}\right)$ \\
\hline$\alpha_{\mathrm{S} 1} \mathrm{CNf}(17-23)$ & 905 & $905.6\left(\mathrm{MH}^{+}\right)+453.5\left(\mathrm{MH}_{2}^{2+}\right)$ \\
\hline$\alpha_{\mathrm{S} 1} \mathrm{CNf}(80-87)$ & 964 & $965.4\left(\mathrm{MH}^{+}\right)+751.1(\mathrm{~b} 6)$ \\
\hline$\alpha_{\mathrm{S} 1} \mathrm{CNf}(24-32)$ & 1,052 & $1052.6\left(\mathrm{MH}^{+}\right)+527.5\left(\mathrm{MH}_{2}^{2+}\right)$ \\
\hline$\alpha_{\mathrm{S} 1} \mathrm{CNf}(111-119) 1 \mathrm{P}$ & 1,094 & $548\left(\mathrm{MH}_{2}{ }^{2+}\right)+365.5\left(\mathrm{MH}_{3}{ }^{3+}\right)$ \\
\hline$\alpha_{\mathrm{S} 1} \mathrm{CNf}(24-34)$ & 1,237 & $1237.7\left(\mathrm{MH}^{+}\right)+619.6\left(\mathrm{MH}_{2}{ }^{2+}\right)+413.0\left(\mathrm{MH}_{3}{ }^{3+}\right)$ \\
\hline$\alpha_{\mathrm{S} 1} \mathrm{CNf}(3-13)$ & 1,283 & $642.5\left(\mathrm{MH}_{2}^{2+}\right)$ \\
\hline$\alpha_{\mathrm{S} 1} \mathrm{CNf}(2-13)$ & 1,380 & $460.9\left(\mathrm{MH}_{3}^{3+}\right)+690.9\left(\mathrm{MH}_{2}{ }^{2+}\right)$ \\
\hline$\alpha_{\mathrm{S} 1} \mathrm{CNf}(2-14)$ & 1,509 & $503.9\left(\mathrm{MH}_{3}^{3+}\right)+755.0\left(\mathrm{MH}_{2}{ }^{2+}\right)$ \\
\hline$\alpha_{\mathrm{S} 1} \mathrm{CNf}(1-13)$ & 1,536 & $385.0\left(\mathrm{MH}_{4}{ }^{4+}\right)+513.0\left(\mathrm{MH}_{3}{ }^{3+}\right)+768.7\left(\mathrm{MH}_{2}{ }^{2+}\right)$ \\
\hline$\alpha_{\mathrm{S} 1} \mathrm{CNf}(1-14)$ & 1,665 & $555.9\left(\mathrm{MH}_{3}^{3+}\right)+833.1\left(\mathrm{MH}_{2}{ }^{2+}\right)$ \\
\hline$\alpha_{\mathrm{S} 1} \mathrm{CNf}(24-38)$ & 1,708 & $570.3\left(\mathrm{MH}_{3}^{3+}\right)+854.5\left(\mathrm{MH}_{2}{ }^{2+}\right)$ \\
\hline$\alpha_{\mathrm{S} 1} \mathrm{CNf}(2-16)$ & 1,721 & $574.6\left(\mathrm{MH}_{3}{ }^{3+}\right)+861.2\left(\mathrm{MH}_{2}{ }^{2+}\right)$ \\
\hline$\alpha_{\mathrm{S} 1} \mathrm{CNf}(1-16)$ & 1,877 & $626.7\left(\mathrm{MH}_{3}{ }^{3+}\right)+939.6\left(\mathrm{MH}_{2}{ }^{2+}\right)+470.0\left(\mathrm{MH}_{4}{ }^{4+}\right)$ \\
\hline$\alpha_{\mathrm{S} 1} \mathrm{CNf}(1-17)$ & 1,991 & $664.7\left(\mathrm{MH}_{3}{ }^{3+}\right)+996.2\left(\mathrm{MH}_{2}{ }^{2+}\right)$ \\
\hline$\alpha_{\mathrm{S} 1} \mathrm{CNf}(1-20)$ & 2,347 & $783.5\left(\mathrm{MH}_{3}{ }^{3+}\right)+587.8\left(\mathrm{MH}_{4}^{4+}\right)+1174.8\left(\mathrm{MH}_{2}{ }^{2+}\right)$ \\
\hline$\alpha_{\mathrm{S} 1} \mathrm{CNf}(1-21)$ & 2,461 & $616.4\left(\mathrm{MH}_{4}{ }^{4+}\right)+821.2\left(\mathrm{MH}_{3}{ }^{3+}\right)+1231.8\left(\mathrm{MH}_{2}{ }^{2+}\right)$ \\
\hline$\alpha_{\mathrm{S} 1} \mathrm{CNf}(1-22)$ & 2,617 & $655.3\left(\mathrm{MH}_{4}{ }^{4+}\right)+873.4\left(\mathrm{MH}_{3}{ }^{3+}\right)+1309.3\left(\mathrm{MH}_{2}{ }^{2+}\right)$ \\
\hline$\alpha_{\mathrm{S} 1} \mathrm{CNf}(6-28)$ & 2,709 & $903.6\left(\mathrm{MH}_{3}{ }^{3+}\right)+1354.9\left(\mathrm{MH}_{2}{ }^{2+}\right)$ \\
\hline$\alpha_{\mathrm{S} 1} \mathrm{CNf}(1-23)$ & 2,764 & $550.0\left(\mathrm{MH}_{5}{ }^{5+}\right)+692.0\left(\mathrm{MH}_{4}{ }^{4+}\right)+922.1\left(\mathrm{MH}_{3}{ }^{3+}\right)$ \\
\hline$\alpha_{\mathrm{S} 1} \mathrm{CNf}(89-110)$ & 2,780 & $695.8\left(\mathrm{MH}_{4}^{4+}\right)+927.5\left(\mathrm{MH}_{3}{ }^{3+}\right)$ \\
\hline$\alpha_{\mathrm{S} 1} \mathrm{CNf}(1-24)$ & 2,908 & $728.0\left(\mathrm{MH}_{4}{ }^{4+}\right)+970.0\left(\mathrm{MH}_{3}{ }^{3+}\right)+1454.6\left(\mathrm{MH}_{2}{ }^{2+}\right)+582.8\left(\mathrm{MH}_{5}{ }^{5+}\right)$ \\
\hline$\alpha_{\mathrm{S} 1} \mathrm{CNf}(1-36)$ & 4,235 & $706.6\left(\mathrm{MH}_{6}{ }^{6+}\right)+848.0\left(\mathrm{MH}_{5}{ }^{5+}\right)+1059.5\left(\mathrm{MH}_{4}{ }^{4+}\right)+1412.6\left(\mathrm{MH}_{3}{ }^{3+}\right)$ \\
\hline$\alpha_{\mathrm{S} 2} \mathrm{CNf}(189-207)$ & 2,332 & $467.4\left(\mathrm{MH}_{5}{ }^{5+}\right)+583.9\left(\mathrm{MH}_{4}{ }^{4+}\right)+778.3\left(\mathrm{MH}_{3}{ }^{3+}\right)$ \\
\hline$\alpha_{\mathrm{s} 2} \mathrm{CNf}(\mathbf{1 8 3}-207)$ & 3,116 & $520.3\left(\mathrm{MH}_{6}{ }^{6+}\right)+624.3\left(\mathrm{MH}_{5}{ }^{5+}\right)+780.4\left(\mathrm{MH}_{4}{ }^{4+}\right)$ \\
\hline$\alpha_{\mathrm{S} 2} \mathrm{CNf}(182-207)$ & 3,217 & $537.2\left(\mathrm{MH}_{6}{ }^{6+}\right)+644.4\left(\mathrm{MH}_{5}{ }^{5+}\right)+805.2\left(\mathrm{MH}_{4}{ }^{4+}\right)+1073.1\left(\mathrm{MH}_{3}{ }^{3+}\right)$ \\
\hline
\end{tabular}

$M W$ molecular weight $(\mathrm{Da})$ 
Table 2 Identified peptides originated from $\beta$-casein found in Asiago d'Allevo cheese

\begin{tabular}{|c|c|c|}
\hline Identification & MW & Characteristic ions $(\mathrm{m} / \mathrm{z})$ \\
\hline$\beta \mathrm{CNf}(4-6)$ & 389 & $390.1\left(\mathrm{MH}^{+}\right)$ \\
\hline$\beta \mathrm{CNf}(3-6)$ & 502 & $503.3\left(\mathrm{MH}^{+}\right)+372.3(\mathrm{~b} 3)$ \\
\hline$\beta \mathrm{CNf}(10-14)$ & 545 & $546.4\left(\mathrm{MH}^{+}\right)+399.3(\mathrm{~b} 4)$ \\
\hline$\beta \mathrm{CNf}(2-6)$ & 631 & $632.4\left(\mathrm{MH}^{+}\right)+501.4(\mathrm{~b} 4)$ \\
\hline$\beta \mathrm{CNf}(47-52)$ & 755 & $756.4\left(\mathrm{MH}^{+}\right)+378.9\left(\mathrm{MH}_{2}^{2+}\right)$ \\
\hline$\beta \mathrm{CNf}(1-6)$ & 787 & $788.4\left(\mathrm{MH}^{+}\right)+657.3(\mathrm{~b} 5)$ \\
\hline$\beta \mathrm{CNf}(7-14)$ & 855 & $856.5\left(\mathrm{MH}^{+}\right)+709.5(\mathrm{~b} 7)+643.4(\mathrm{y} 6)$ \\
\hline$\beta \mathrm{CNf}(84-93)$ & 1,156 & $579.0\left(\mathrm{MH}_{2}^{2+}\right)+1156.7\left(\mathrm{MH}^{+}\right)$ \\
\hline$\beta \mathrm{CNf}(83-93)$ & 1,255 & $628.5\left(\mathrm{MH}_{2}^{2+}\right)+1255.8\left(\mathrm{MH}^{+}\right)$ \\
\hline$\beta \mathrm{CNf}(82-95)$ & 1,510 & $756.1\left(\mathrm{MH}_{2}{ }^{2+}\right)+504.3\left(\mathrm{MH}_{3}{ }^{3+}\right)$ \\
\hline$\beta \mathrm{CNf}(193-206)$ & 1,555 & $1556.8\left(\mathrm{MH}^{+}\right)+778.7\left(\mathrm{MH}_{2}{ }^{2+}\right)+519.6\left(\mathrm{MH}_{3}{ }^{3+}\right)$ \\
\hline$\beta \mathrm{CNf}(17-28) 3 \mathrm{P}$ & 1,590 & $795.8\left(\mathrm{MH}_{2}{ }^{2+}\right)+530.9\left(\mathrm{MH}_{3}{ }^{3+}\right)$ \\
\hline$\beta \mathrm{CNf}(193-208)$ & 1,781 & $891.7\left(\mathrm{MH}_{2}^{2+}\right)+1781.9\left(\mathrm{MH}^{+}\right)$ \\
\hline$\beta \mathrm{CNf}(15-28) 3 \mathrm{P}$ & 1,790 & $896.0\left(\mathrm{MH}_{2}{ }^{2+}\right)+597.7\left(\mathrm{MH}_{3}{ }^{3+}\right)$ \\
\hline$\beta \mathrm{CNf}(193-209)$ & 1,881 & $941.2\left(\mathrm{MH}_{2}{ }^{2+}\right)+627.7\left(\mathrm{MH}_{3}{ }^{3+}\right)$ \\
\hline$\beta \mathrm{CNf}(12-28) 4 \mathrm{P}$ & 2,212 & $1106.7\left(\mathrm{MH}_{2}{ }^{2+}\right)+738.1\left(\mathrm{MH}_{3}{ }^{3+}\right)+553.8\left(\mathrm{MH}_{4}{ }^{4+}\right)$ \\
\hline$\beta \mathrm{CNf}(11-28) 4 \mathrm{P}$ & 2,340 & $1170.9\left(\mathrm{MH}_{2}{ }^{2+}\right)+780.8\left(\mathrm{MH}_{3}{ }^{3+}\right)+585.8\left(\mathrm{MH}_{4}{ }^{4+}\right)$ \\
\hline$\beta \mathrm{CNf}(8-28) 4 \mathrm{P}$ & 2,594 & $1298.0\left(\mathrm{MH}_{2}{ }^{2+}\right)+865.5\left(\mathrm{MH}_{3}{ }^{3+}\right)+649.7\left(\mathrm{MH}_{4}{ }^{4+}\right)$ \\
\hline$\beta \mathrm{CNf}(98-124)$ & 3,133 & $1567.3\left(\mathrm{MH}_{2}{ }^{2+}\right)+1044.9\left(\mathrm{MH}_{3}{ }^{3+}\right)+784.3\left(\mathrm{MH}_{4}{ }^{4+}\right)$ \\
\hline$\beta \mathrm{CNf}(59-96)$ & 4,024 & $1342.7\left(\mathrm{MH}_{3}{ }^{3+}\right)+1007.1\left(\mathrm{MH}_{4}{ }^{4+}\right)+805.8\left(\mathrm{MH}_{5}{ }^{5+}\right)$ \\
\hline
\end{tabular}

$M W$ molecular weight (Da)

reported but only at relatively high concentrations $\left(0.1\right.$ to $\left.1 \mathrm{mg} \cdot \mathrm{mL}^{-1}\right)$ (Gobbetti et al. 2004). Bovine $\alpha_{\mathrm{s} 2}-\mathrm{CN}$ has shown to be a precursor of several antibacterial peptides. The C-terminal cationic fragment of the protein $\alpha_{\mathrm{s} 2}-\mathrm{CN} f(183-207)$ displayed inhibitory activity against several Gram-positive and Gram-negative bacteria (Recio and Visser 1999) and was found in all Asiago WSEs.

Figure 2 shows the average relative content of these two peptides (peptides XIC area/Phe-Phe XIC area) as a function of cheese ripening time. $\alpha_{\mathrm{s} 1}-\mathrm{CN} f(1-23)$

Fig. 2 Average relative amounts of antimicrobial peptides (A/A i.s., peptide XIC area/Phe-Phe XIC area of internal standard) in cheeses ripened for 6 (white square), 12 (medium shade square), and 18 (dotted square) months

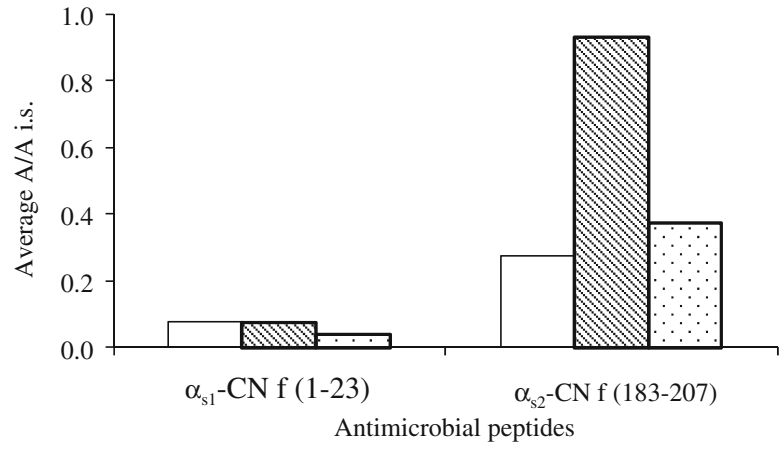


concentration in cheese was lower after ripening for 18 months than for either 12, or 6 months. Since this peptide corresponds to the primary site of cleavage of $\alpha_{\mathrm{s} 1}-\mathrm{CN}$ by chymosin during primary cheese proteolysis, the decrease of its concentration after ripening for 18 months likely results from further breakdown into inactive peptides as a result of the prolonged action of endo- and/or exo-peptidases. The concentrations of $\alpha_{\mathrm{s} 2}-\mathrm{CN} f(183-207)$ were higher in samples ripened for 12 months than in cheeses ripened for either 6 , or 18 months: This could thus not explain why the L. innocua inhibitory activity was maximal in the cheeses ripened for 6 months. This suggests that other AMPs in Asiago cheese likely contributed to the L. innocua LRGIA 01 growth inhibition. In fact, some peptides with slightly longer or shorter sequences compared with known AMPs, such as $\alpha_{\mathrm{s} 2}-\mathrm{CN} f(182-207)$, which can show a similar structure to $\alpha_{\mathrm{s} 2}-\mathrm{CN} f(183-207)$ were also identified in Asiago cheese and might also be responsible for the anti-listerial activity.

\section{Conclusions}

The water-soluble fractions of cheese are known to contain a wide amount of proteolytic products that range from small proteins to peptides, amino acids, and protein/peptide-derived nitrogen compounds such as amines, urea, and ammonia. In contrast to most of the data that have been reported in literature, WSEs that were not fractionated by liquid chromatography were considered within this study. Water-soluble molecules extracted from Asiago cheese significantly inhibited L. innocua LRGIA 01 but not L. monocytogenes strain 102 . The length of ripening time but not the production system of cheeses and the corresponding variations in cows feeding, milking, and cheese-making conditions affected their anti-L. innocua LRGIA 01 activity. The identification of two fragments of caseins $\left(\alpha_{\mathrm{s} 1}-\mathrm{CN} f(1-23)\right.$ and $\left.\alpha_{\mathrm{s} 2}-\mathrm{CN} f(183-207)\right)$ known for their antimicrobial activity suggest the contribution of antimicrobial casein fragments to the anti-listerial activity. However, evidencing that there was no direct correlation between the concentration of known antimicrobial fragments of caseins identified in Asiago d'Allevo cheeses and their L. innocua LRGIA 01 growth inhibitory activity, other antimicrobial peptides still have to be identified. Further work is now needed to identify whether these peptides are other yet unknown antimicrobial fragments of caseins instead of bacteriocins produced by the bacterial ecosystem of cheese curd (Nuñez et al. 1997).

Acknowledgments This research was financed by FONDAZIONE CARIVERONA. The authors thank Aerial (Schiltigheim, France) for kindly providing the L. monocytogenes strain 162 that was submitted to test in this study.

\section{References}

Adrião A, Vieira M, Fernandes I, Barbosa M, Sol M, Tenreiro RP, Chambel L, Barata B, Zilhao I, Shama G, Perni S, Jordan SJ, Andrew PW, Faleiro ML (2008) Marked intra-strain variation in response of Listeria monocytogenes dairy isolates to acid or salt stress and the effect of acid or salt. Int J Food Microbiol 123:142-150 
Alvarez-Cisneros YM, Fernandez FJ, Wacher-Rodarte C, Aguilar MB, del Rosario Sainz Espunes, PonceAlquicira E (2010) Biochemical characterization of a bacteriocin-like inhibitory substance produced by Enterococcus faecium MXVK29, isolated from Mexican traditional sausage. J Sci Food Agric 90:2475-2481

Chadeau E, Oulahal N, Dubost L, Favergeon F, Degraeve P (2010) Anti-listerial innocua activity of silver functionalised textile prepared with plasma technology. Food Control 21:505-512

Floris R, Recio I, Berkhout B, Visser S (2003) Antibacterial and antiviral effects of milk proteins and derivatives thereof. Curr Pharm Des 9:1257-1273

Gobbetti M, Minervini F, Rizzello CG (2004) Angiotensin I-converting-enzyme-inhibitory and antimicrobial bioactive peptides. Int J Dairy Technol 57:173-188

Lahov E, Regelson W (1996) Antibacterial and immunostimulating casein-derived substances from milk: casecidin, isracidin peptides. Food Chem Toxicol 34:131-145

Lignitto L, Cavatorta V, Balzan S, Gabai G, Galaverna G, Novelli E, Sforza S, Segato S (2010) Angiotensin-converting enzyme inhibitory activity of water-soluble extracts of Asiago d'Allevo cheese. Int Dairy J 20:11-17

López Expósito I, Recio I (2006) Antibacterial activity of peptides and folding variants from milk proteins. Int Dairy J 16:1294-1305

McCann KB, Shiell BJ, Michalski WP, Lee A, Wan J, Roginski H, Coventry MJ (2005) Isolation and characterisation of antibacterial peptides derived from the $\mathrm{f}(164-207)$ region of bovine $\alpha_{\mathrm{s} 2}$-casein. Int Dairy J 15:133-143

McCann KB, Shiell MWP, Lee A, Wan J, Roginski H, Coventry MJ (2006) Isolation and characterisation of a novel antibacterial peptide from bovine $\alpha_{\mathrm{s} 1}$-casein. Int Dairy J 16:316-323

Mariani C, Oulahal N, Chamba JF, Dubois-Brissonnet F, Notz E, Briandet R (2011) Inhibition of Listeria monocytogenes by resident biofilms present on wooden shelves used for cheese ripening. Food Control 22:1357-1362

Mukherjee K, Abu Mraheil M, Silva S, Muller D, Cemic F, Hemberger J, Hain T, Vilcinskas A, Chakraborty T (2011) Anti-listerial activities of Galleria mellonella hemolymph proteins. Appl Env Microbiol 77:4237-4240

Nuñez M, Rodríguez JL, García E, Gaya P, Medina M (1997) Inhibition of Listeria monocytogenes by enterocin 4 during the manufacture and ripening of Manchego cheese. J Appl Microbiol 83:671-677

Pritchard SR, Phillips M, Kailasapathy K (2010) Identification of bioactive peptides in commercial Cheddar cheese. Food Res Int 43:1545-1548

Recio I, Visser S (1999) Identification of two distinct antibacterial domains within the sequence of bovine $\alpha_{\mathrm{s} 2}$-casein. Biochim Biophys Acta 1428:314-326

Rizzello CG, Losito I, Gobbetti M, Carbonara T, De Bari MD, Zambonin PG (2005) Antibacterial activities of peptides from water-soluble extract of Italian cheese varieties. J Dairy Sci 88:2348-2360

Segato S, Balzan S, Elia CA, Lignitto L, Granta A, Magro L, Contiero B, Andrighetto I, Novelli E (2007) Effect of period of milk production and ripening on quality traits of Asiago cheese. Ital J Anim Sci 6 (suppl1):469-471

Sforza S, Ferroni L, Galaverna G, Dossena A, Marchelli R (2003) Extraction, semi-quantification, and fast on-line identification of oligopeptides in Grana Padano cheese by HPLC-MS. J Agric Food Chem 51:2130-2135

Zucht HD, Raida M, Adermann K, Mägert HJ, Forssmann WG (1995) Casocidin-I: a casein- $\alpha_{\mathrm{s} 2}$ derived peptide exhibits antibacterial peptides. FEBS Lett 372:185-188 